\title{
An Innovative Methodology for Groundwater Management with Reference to Saline Water Intrusion
}

\author{
${ }^{1}$ Dr. Amartya Kumar Bhattacharya, ${ }^{2}$ Dr. Sudip Basack, ${ }^{3}$ Prabir Maity \\ ${ }^{1}$ Associate Professor, Department of Applied Mechanics, Bengal Engineering and Science University, Shibpur, \\ Howrah - 711103, West Bengal, INDIA. \\ ${ }^{2}$ Associate Professor, Department of Applied Mechanics, Bengal Engineering and Science University, Shibpur, \\ Howrah - 711103, West Bengal, INDIA. \\ ${ }^{3}$ Research Scholar, Department of Applied Mechanics, Bengal Engineering and Science University, Shibpur, \\ Howrah - 711103, West Bengal, INDIA.
}

\begin{abstract}
An innovative method of control of saltwater intrusion into the coastal aquifers has been suggested in this paper. A new method consists of withdrawal by qanat-well structures with reasonable compensation by rainwater harvesting by means of recharge ponds and recharge well. The salient features of the methodology are described by considering a design example adopted in the Contai Polytechnic Institute Campus of the district of Purba Midnapur in the state of West Bengal, India.
\end{abstract}

KEY WORDS: - Coastal Environment, Geotechnical Investigation, Mathematical Analysis, Management and Control of Saline Water Intrusion, Quantitative Analysis

\section{INTRODUCTION}

Groundwater is the second largest reserve of freshwater on earth. About 2 billion people, approximately one-third of the world's population, depend on groundwater supplies, withdrawing about 20 per cent of global water $\left(600-700 \mathrm{~km}^{3}\right)$ annually - much of it from shallow aquifers ( Patra et al 2006). India cities located near coastlines with large population can experience saline water intrusion due to overexploitation of groundwater, causing this significant threat to freshwater resources. Sustainability strategies adopted to retard or halt the rate of saline water intrusion are necessary to protect the resources from further damage. The complexity of hydrogeological set up in the concerned area calls for scientific management techniques to be adopted in the groundwater development. This requires a clear understanding of the hydrogeology of the area concerned, appreciation of the possible consequence of over or under developments and a coordinated approach of the planners, hydrogeologists, irrigation engineers, social scientists in the field (Bhattacharya et al 2004). Excessive withdrawal of groundwater in coastal zones will lead to depression of water table with associated hazards like putting the well out of use, rendering the abstraction uneconomic with increased lift. A sustained regional groundwater drawdown below sea level runs risk of saline water intrusion, even for confined coastal aquifers. A careful pumping and rest schedule may help in avoiding many such problems. An uncontrolled groundwater development may lead to reversal of fresh water gradient thereby resulting in saline water ingress into the coastal aquifers. For example, reports of salinisation of wells subjected to continuous heavy pumpage in coastal district of Purba Midnapur, West Bengal, India though few, are not uncommon.

As suggested by various Scientists and Engineers, there are several established methodologies to control and minimise the problems associated with groundwater extraction followed by saline water intrusion. Some of the popular methods adopted are: creation of hydraulic barrier, rainwater harvesting, artificial recharge, canal irrigation, desalination and reverse osmosis etc.

However, the author has developed an innovative cost-effective techniques to control salt water intrusion into coastal aquifers; the techniques includes withdrawal of coastal fresh water by means of qanat-well structures associated with artificial recharge through rainwater harvesting aided with percolation pond and recharge well. A case study on a selected location of the coastal zone of Purba Midnapur has been carried out. Adequate quantifications of the effectivity of this new methodology have been incorporated and relevant conclusions are drawn there from.

\section{A NEW APPROACH FOR CONTROL OF SALINE WATER INTRUSION INCOASTAL} AREAS

While a numerical simulation method like the finite difference or finite element scheme might be very illuminating from a research point of view, it is unlikely that field engineers will be able to capture the intricacies of such an approach. Keeping this in view; an innovative analytical method which is appropriate and 
at the same time easily implemental; is adopted as a new approach for groundwater withdrawal and control of saline water intrusion in the study area.It is evident that any withdrawal of groundwater from a coastal aquifer results in advancement of the saltwater-freshwater interface from the shoreline towards to the point of withdrawal (Todd, 1976) unless the withdrawal is compensated by an equivalent artificial recharge. The rainwater harvesting is one of the most popular recharge techniques followed worldwide (UNEP Report, 2009). In the proposed methodology for reduction of saline water intrusion into the coastal aquifer and subsequent safe withdrawal of groundwater, the adoption of qanat-well structure associated with artificial recharge by rainwater harvesting through recharge ponds and recharge wells is hereby studied as one of the useful and cost-effective techniques. The salient features of the methodology are described by considering a design example adopted by the author in the Contai Polytechnic Institute Campus of the district of Purba Medinipur in the state of West Bengal.

\section{Adoption of Qanat-Well Structure}

The inland aquifers are suffering from the maladies of over exploitation of groundwater by way of unscrupulous pumping; the coastal aquifers encounter the danger of sea water intrusion and saline water upconing.

Due to saltwater intrusion, deep tube-well is not recommended because of the upconing problem. However, adoption of shallow well is also inappropriate because of significantly lower discharge. It is well established (Raghu Babu et al., 2004) that adoption of qanats in such conditions not only yields higher discharge but also reduces the upconing problem significantly.

Horizontal wells are more efficient than conventional vertical wells for environmental remediation of groundwater for a number of reasons such as:

* Greater reservoir contact with the well screen increases the productivity of the well.

* Geometry of the groundwater zone is conducive to greater access with a horizontal well than a series of vertical wells.

* Access to groundwater zones with vertical wells are often hindered by obstacles such as buildings, paved surfaces, or other topographical obstructions.

Beljin and Losonsky (1992) provided a generalized solution, based on the work of Joshi (1986), for estimating steady-state discharge for withdrawal of groundwater from a vertical aquifer by means of horizontal water well. The solution provided was given by:

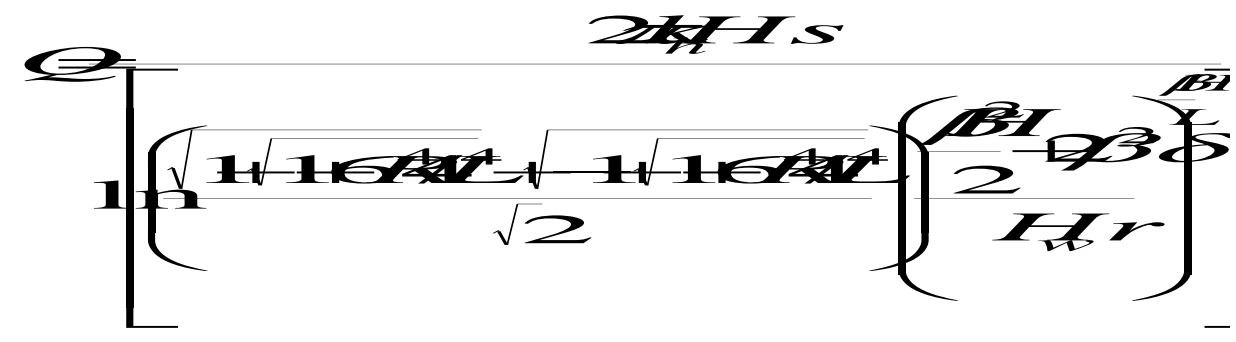

(1)

where, $\mathrm{Q}=$ Steady state discharge.

$\mathrm{s}=$ Drawdown above the well centre.

$\mathrm{L}=$ Length of the horizontal well.

$\mathrm{r}_{\mathrm{w}}=$ Well radius.

$\mathrm{k}_{\mathrm{h}}=$ Hydraulic conductivity of the aquifer along horizontal direction.

$\mathrm{H}=$ Aquifer thickness.

$\beta=\left(\mathrm{k}_{\mathrm{h}} / \mathrm{k}_{\mathrm{v}}\right)^{0.5}$

$\mathrm{k}_{\mathrm{v}}=$ Hydraulic conductivity of the aquifer along vertical direction.

$\delta=$ Off-centered eccentricity of the well-centre in the vertical aquifer plane.

$\mathrm{R}=$ Radius of influence of the equivalent vertical well in the same aquifer for the same drawdown, which can be reasonably estimated using the available correlations (for example, Sichardt's formulae).

The above equation has been modified, applying the method of superimposition, to reasonably estimate the steady-state discharge by means of a 4 legged qanat. The final expression is obtained as: 


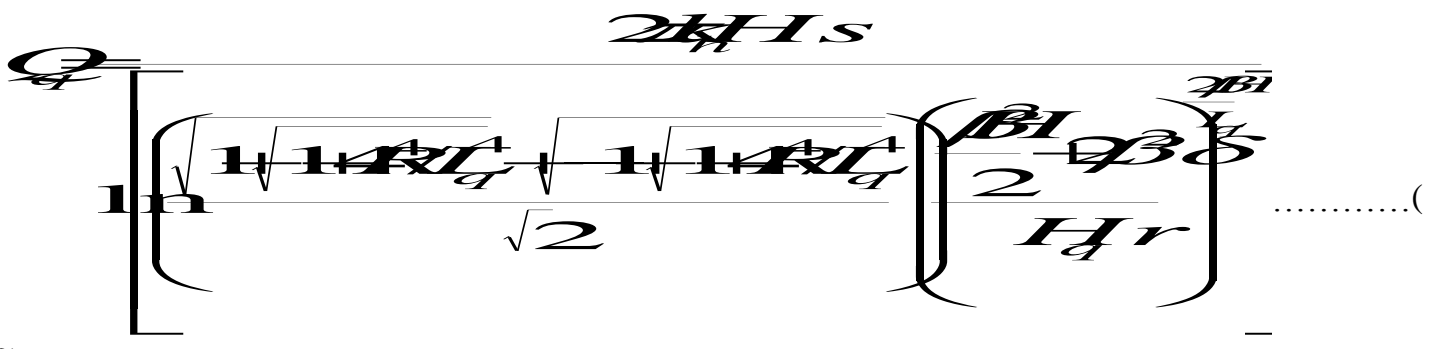

2)

where, $\mathrm{Q}_{\mathrm{q}}=$ Steady state discharge from the qanat.

$\mathrm{L}_{\mathrm{q}}=$ Length of a qanat leg (See Fig.1).

$\mathrm{r}_{\mathrm{q}}=$ Inner radius of qanat legs.

The maximum discharge from the qanat under full flow condition can be obtained by putting $\mathrm{s}=\mathrm{d}-2 \mathrm{r}_{\mathrm{q}}$ (neglecting the wall thickness of the qanat legs) in the Eq. (2) above. Thus,

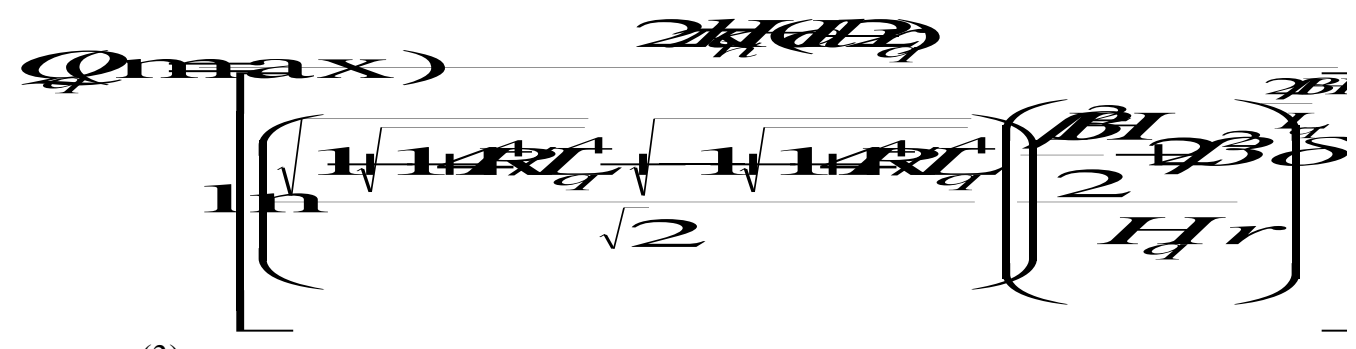

where, $\mathrm{Q}_{\mathrm{q}}(\max )=$ Maximum possible discharge from the qanat.

$\mathrm{d}=$ Depth of the bottom surface of the qanat legs below the undisturbed water table.

Using Sichardt's formulae $\mathrm{R}=3000\left(\mathrm{~d}-2 \mathrm{r}_{\mathrm{q}}\right) \square \mathrm{k}_{\mathrm{h}}$ in Eq.(3), where all terms should essentially be in SI units, the Eq.(3) above can be written as:

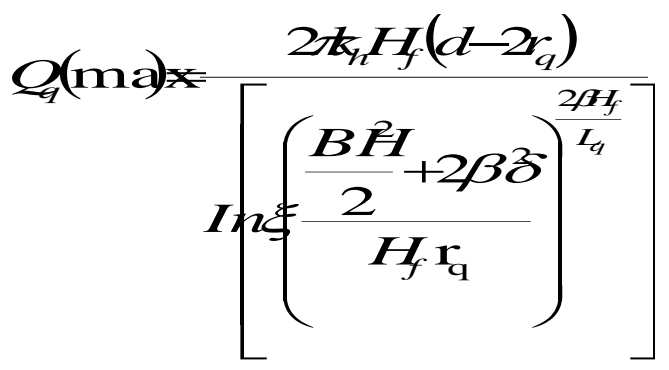

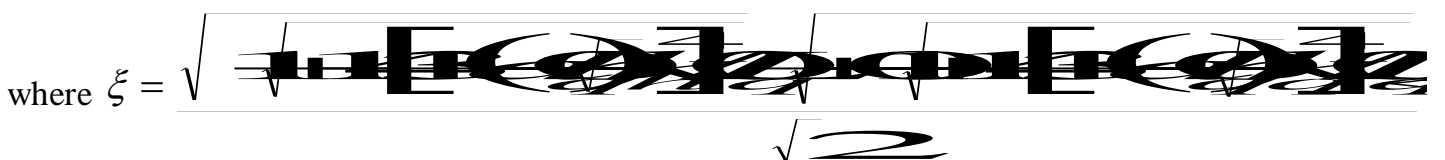

Although upconing in case of qanat-well structures is apparently not practical specifically when the saltwater -freshwater interface is situated at a significant depth below the bottom of the structures, the upconing problem may be catastrophic for shallow depth of interface in the area near the sea. Therefore, the present analysis is extended considering upconing as well (Fig.2).

After the recommendation of Dagan and Bear (1968):

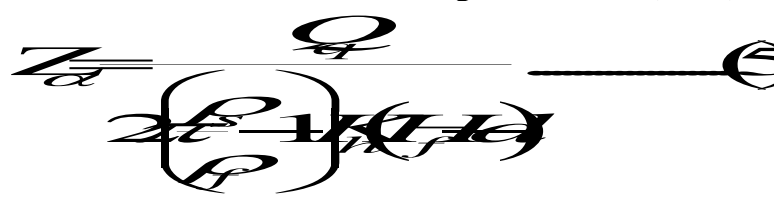


Where, $Z_{\infty}=$ the value of $Z$ at infinite time. The value of $Q$ attains the maximum value when $Z_{\infty}=H_{f}-d$

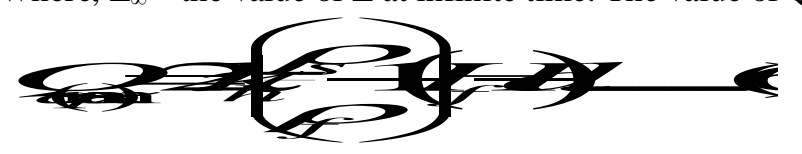

The optimum values of $\mathrm{Q}_{\mathrm{q}(\max )}$ shall be the least of the two values obtained from the equation (4) and (6). It is hereby mentioned that the design values of the depth of qanat-well structures is calculated as unrealistically high, therefore not feasible, the number of such qanat-well structures may be reasonably increased as required.

\section{Groundwater Recharge by Rainwater Harvesting}

A hybrid method considering ponds and recharge wells is adopted to (i) combine the best of both, (ii) providing only ponds would eat up a huge amount of unnecessary spaces, (ii) providing only wells would necessitates pressure injection into the aquifer. Therefore, since due to space constraint in the locality under consideration, the full recharge may not be affected by pond, recharge wells are needed. The withdrawal of groundwater by qanat should be suitably compensated by recharge with rainwater harvesting, the salient features of this new approach with adequate quantification is described below.

\section{Recharge Area}

If fresh water in a coastal area is withdrawal regularly, the saltwater-freshwater interface is progressively advanced horizontally as well as vertically unless the withdrawal is subsequently compensated by a suitable artificial groundwater recharge techniques. The method proposed herein includes rainwater harvesting by means of recharge ponds and recharge wells design.

Usually for a particular community, neglecting the area of recharge well,

$A_{t}=A_{\text {roof }}+A_{\text {road }}+A_{\text {pond }}+A_{1}$

where, $A_{t}=$ Total area of the community.

$\mathrm{A}_{\text {roof }}=$ Total roof cover area for all building in the community.

$\mathrm{A}_{\text {road }}=$ Total road area in the community.

$\mathrm{A}_{\mathrm{road}}=$ Total pond area of the community.

$\mathrm{A}_{1}=$ Total area of vacant land in the community.

\section{Factor of Safety for Rainfall Recharge}

For a particular community in a coastal area, the net volume of freshwater withdrawal in a certain period of time should not exceed the available volume of recharge for that period. With this conception, the corresponding factor of safety for the particular community has been formulated for the volumetric constancy as:

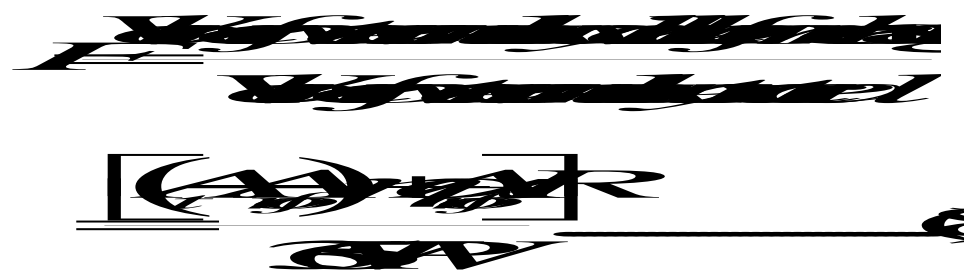

where, $\mathrm{W}=$ Average water

in litre per capita per day.

$=140 \mathrm{lit} / \mathrm{Capita} / \mathrm{Day}$

$\mathrm{P}=$ Population of the community.

$\mathrm{R}=$ Design annual rainfall in $\mathrm{mm}$.

$\eta=$ Recharge coefficient.

$\alpha=$ Fraction of rainwater collected at roof which in directed towards the recharge well.

It is hereby mentioned that this technique is most effective when the value of the factor of safety is slightly higher than unity. Excessively high value of the factor of safety may be necessitated adequate drainage facility in the area under consideration to avoid the undesirable circumstance like water logging and flooding. Conversely, when the value of the factor of safety is less than unity, situation can be compensated either by reducing the withdrawal of groundwater or by increasing the catchments area for rainfall recharge.

\section{Percolation Pond}

The design precipitation chosen depends on the design return period of the precipitation. The longer the design returns period, the greater the precipitation. After recommendation by Sarkar (2007), the water collected from the roof area in the community is partly allowed to percolate through recharge chamber cum recharge well 
and the remaining portion is stored for future usage like fire fighting and domestic use etc. Therefore, the total area of recharge pond for the community under consideration may be estimated reasonably considering the net volume of water to be stored in the pond during the monsoon period. Therefore,

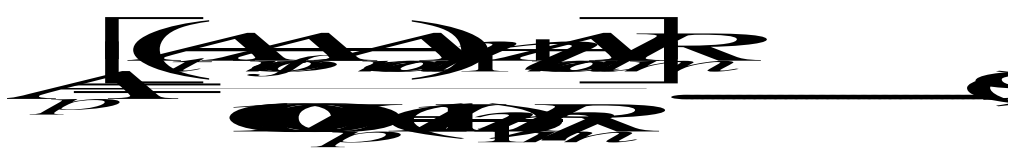

where $A_{p}=$ Area of the Pond.

$\mathrm{R}_{\mathrm{m}}=$ Design monsoon rainfall in $\mathrm{mm}$.

$\eta_{1}=$ Runoff coefficient relevant to the area.

$\mathrm{H}_{\mathrm{p}}=$ Depth of pond to be excavated.

\section{Recharge Chamber with Recharge Well}

As already mention earlier Sarkar (2007) designed a rainwater harvesting scheme for TCS building Salt Lake, Kolkata, India. Following his recommendations, the dimensions and number of recharge chamber fitted with $100 \mathrm{~mm}$ diameter recharge well for the community under consideration may be reasonably estimated by:

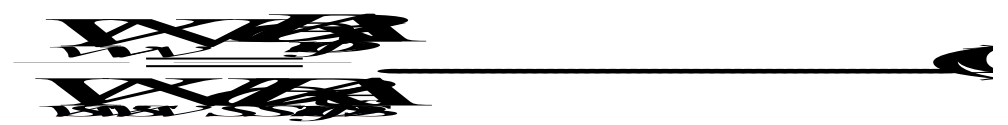

where $\mathrm{V}_{\mathrm{w}}=$ Volume of the recharge chamber in the community.

$\mathrm{N}_{\mathrm{w}}=$ Nos. of recharge chamber fitted with 100 dia. recharge well adopted in the community. The suffix 's' denotes the corresponding parameter for the relevant to Sarkar ( 2007).

From the field investigation, SP reading is observed to move towards negative side indicating presence of sand aquifer below. As observed, the average depth freshwater-saltwater interface is situated at a depth of about 40m below the ground surface. It is advisable not to go for 'Deep Tube Well' construction; Qanat-Well Structures is preferable in this situation.

The input parameters necessary for design in the locality under consideration are summarised below in Table 1 .

Table 1: Values of variables determined from hydrogeological investigation

\begin{tabular}{|l|l|}
\hline \multicolumn{1}{|c|}{ Input Parameter } & \multicolumn{1}{c|}{ Values } \\
\hline Maximum design discharge, $\mathrm{Q}_{\mathrm{q}(\mathrm{Max})}$ & Calculated using Equations 4 and 6 \\
\hline Aquifer thickness, $\mathrm{H}$ & $40 \mathrm{~m}$ \\
\hline Horizontal hydraulic conductivity, $\mathrm{K}_{\mathrm{h}}$ & $3.512 \times 10^{-4} \mathrm{~m} / \mathrm{sec}$, [ Laboratory test] \\
\hline Vertical hydraulic conductivity, $\mathrm{K}_{\mathrm{V}}$ & $3.614 \times 10^{-4} \mathrm{~m} / \mathrm{sec}$, [ Laboratory test] \\
\hline Conductivity contrast, $\beta=\sqrt{\frac{\boldsymbol{K}_{\mathbf{h}}}{\boldsymbol{K}_{\nu}}}$ & 0.9857 \\
\hline Well eccentricity, $\delta$ & 0 \\
\hline Population in Contai Polytechnic College Campus, $\mathrm{P}$ & 300 \\
\hline Total Area of the College Campus, $\mathrm{A}_{\mathrm{t}}$ & $90169 \mathrm{~m}^{2}$ \\
\hline Total Roof Area including Student Hostels, $\mathrm{A}_{\mathrm{r}}$ & $12000 \mathrm{~m}^{2}$ \\
\hline Total Road area $\mathrm{A}_{\mathrm{r}}$ & $1010 \mathrm{~m}^{2}$ \\
\hline Total area of pond, $\mathrm{A}_{\mathrm{p}}$ & $1204 \mathrm{~m}^{2}$ \\
\hline Area of vacant land $\mathrm{A}_{1}$ & $75955 \mathrm{~m}^{2}$ \\
\hline Design annual precipitation, $\mathrm{R}$ & Various values are taken \\
\hline Design monsoon precipitation, $\mathrm{R}_{\mathrm{m}}$ & Various values are taken \\
\hline Per Capita water consumption, $\mathrm{W}$ & 140 Litre/Capita/Day \\
\hline Recharge coefficient, $\eta$ & Chosen from available literature \\
\hline Runoff coefficient, $\eta_{1}$ & \multicolumn{1}{c|}{ do - } \\
\hline
\end{tabular}




\section{Application of New Approach}

From the available groundwater data, the coastal areas in the district of Purba Medinipur mostly consist of unconfined aquifers, with the average freshwater table of 2-3m below the ground surface (Goswami, 1968 and Sarkar, 2005) and the average saline water and fresh water interface varies in the range of $0-100 \mathrm{~m}$. The aquifer is unconfined having an average hydraulic conductivity of $\mathrm{k}_{\mathrm{h}}=3.512 \times 10^{-4} \mathrm{~m} / \mathrm{s}$ and $\mathrm{k}_{\mathrm{v}}=3.614 \times 10^{-4} \mathrm{~m} / \mathrm{s}$. From the available data (UNDP Report, 2006 and WHO/UNICEF Report, 2010), the value of W (water demand) has been chosen as 140 litre/capita/day. The average population in the campus is 250 . Considering a $20 \%$ increase, the value of $\mathrm{P}$ is taken as 300 . On the basis of water demand per day for the College Campus with pumping operation per day such as 2 hrs., 3 hrs., 4 hrs., 5 hrs., the qanat-well structures with different parameter such as length, radius and depth of qanat is calculated using the equation (4). The $\mathrm{Q}_{\mathrm{q}(\max )}$ has been calculated as follows:

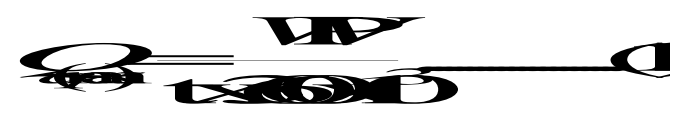

where, $\mathrm{t}=$ Hourly pumping rate in the college campus per day.

Using equation (4), the values of the depth of the qanat base for the chosen value of $\mathrm{L}_{q}$ and $\mathrm{r}_{\mathrm{q}}$ is calculated.

This value of ${ }^{\prime} \mathrm{d}^{\prime}$ is back-figured in the equation (6) to check for upconing. If the discharge calculated from the equation (6) exceeds the design discharge as estimated previously, upconing does not take place. Otherwise, the depth' $d$ ' may be calculated using equation (6). It is observed that at the College Campus, the upconing does not occur.

As observed from Fig. 3, the parameter d decreases following a curvilinear pattern with the length of leg $\mathrm{L}_{\mathrm{q}}$. The variation is quite sharp in the range of $1 \mathrm{~m} \leq \boldsymbol{L}_{\boldsymbol{q}} \leq \mathbf{n}$ and assumes a linear pattern for $\mathrm{L}_{\mathrm{q}}>3 \mathrm{~m}$. The above curves will be helpful for design Engineer to adopt suitable values of the qanat parameter $r_{q}, L_{q}, d, t$ considering other design aspect such as, maximum depth of water table, feasibility of construction etc.

\section{Recharge Structures}

\section{Rainfall Recharge}

From the available literature (State Forest Report, 2008-09 and Annual Climate Summery, 2010), the total annual rainfall in the district of Purba Medinipur of the state of West Bengal, India for the decade 20012010 varies in the range of $1296-2259 \mathrm{~mm}$. For design of recharge pond equipped with recharge-wells for the given community, the factor of safety $\mathrm{F}$ for recharge may be estimated using the equation (8), using the following data:

$A_{t}=90169 \mathrm{~m}^{2}$

$\mathrm{A}_{\text {roof }}=12000 \mathrm{~m}^{2}$

The value of the recharge coefficient $\eta$ may be reasonable estimated from the available literature ( e.g. Wu \& Zhang, 1994, Chaturvedi,1936 and Kumar, 2002 ).

Wu and Zhzng (1994) calculated the effective precipitation $P_{e}$ and the total amount of recharge $R_{e}$ produced by $\mathrm{P}_{\mathrm{e}}$. By performing a regression analysis on $\mathrm{P}_{\mathrm{e}}$ and $\mathrm{R}$ data available in China, a functional relationship between them was obtained as:

$R_{e}=0.87\left(P_{e}-27.4\right)$

where $\mathrm{R}_{\mathrm{e}}=$ Infiltration Recharge in $\mathrm{mm}$

$\mathrm{P}_{\mathrm{e}}=$ Effective Rainfall in $\mathrm{mm}$

Chaturvedi (1936) derived an empirical relationship to arrive at the recharge as a function of annual precipitation in Ganga-Yamuna doab basin as follows:

$\mathrm{R}=2.0(\mathrm{P}-15)^{0.4}$

Where, $\mathrm{R}=$ net recharge due to precipitation during the year (inch).

$\mathrm{P}=$ annual precipitation (inch).

The formula of Chaturvedi (1936) was later modified further by Kumar \& Seethapathi (2002) and the modified form of the formula is:

$\mathrm{R}=1.35(\mathrm{P}-14)^{0.5}$ 
As observed from Fig.4, the factor of safety increases linearly with increase in annual precipitation, which is well in agreement with the equation (8). Also, the curves relevant to those of Chaturvedi (1936) and Kumar and Seethapathi (2002) almost coincide. Both the magnitudes and the slope of the curve relevant to that of Wu and Zhzng (1994) are significantly high.

\section{Percolation Pond}

The runoff should be assessed accurately for designed the recharge structures and may be assessed by following formula.

Runoff=Catchments area $x$ Rainfall $x$ Runoff coefficient

Runoff coefficient plays an important role in assessing the runoff availability and it depends upon the catchments characteristics. It is the factor that accounts for the fact that not all rainfall falling on catchments can be collected. Some rainfall will be lost from the catchments by evaporation and retention on the surface itself.

As observed from Fig.5, the required area of recharge pond decreases in a hyperbolic maner with the depth of pond to be excavated, which is well in agrement with equation (9).

\section{Recharge Chamber with Recharge Well}

The relevant calculations for recharge chamber with recharge well are described below.

As observed from Fig.6, the number of recharge chambers $\mathrm{N}_{\mathrm{w}}$ decreases fairly exponentially with the volume $\mathrm{V}_{\mathrm{w}}$ of the recharge chambers. The rate of decrease is pronounced in the range of $\mathrm{V}_{\mathrm{w}}, 5$, beyond which a stabilizing tendency is noted.

\section{Appropriate Engineering Design}

The appropriate site-specific engineering design is suggested by the author following the analysis described above in details.

\section{(a) Qanat-well Structure:}

The following parameters are suggested:

$\mathrm{t}=3$ hours.

$\mathrm{r}_{\mathrm{q}}=125 \mathrm{~mm}$

$\mathrm{L}_{\mathrm{q}}=2.5 \mathrm{~m}$

$\mathrm{d}=3.25 \mathrm{~m}$

[For future safety provision, 2 qanat-well structures are recommended for alternative use]

There, design depth of the qanat below G.L. $=\mathrm{d}+$ maximum depth of G.W.T. $=3.25+3=6.25 \mathrm{~m}$

\section{(b) Factor of Safety:}

The factor of safety for minimum and maximum rainfall are obtained as $[\alpha=0.5]$,

$\underline{\text { Rainfall }}$

Minimum

Maximum

\section{Factor of Safety}

6.135 (after Wu \& Zhzng, 1994)

1.586 (after Chaturvedi, 1936)

1.565 (after Kumar \& Seethapathi, 2002)

10.786 (after Wu \& Zhzng, 1994)

2.321 (after Chaturvedi, 1936)

2.387 (after Kumar \& Seethapathi, 2002)

For Indian condition, the recommended value as per Kumar and Seethapathi (2002) is mostly suitable. It is also mentioned here that the value of factor of safety under minimum rainfall in last 10 years should not fall below 1.0., therefore satisfactory in terms of reasonable compensation of withdrawal of groundwater. Also, under maximum rainfall in last 10 years, the factor of safety exceeds 2.0, which may introduce sufficient push back of saline water interface. It should also be mentioned here that for excessive high value of factor of safety, adequate drainage should facilitated at the site towards nearby stream channel. 


\section{(c) Area and depth of Percolation Pond}

From Fig.5, the design rainfall data has been chosen as $R_{m}=367.1 \mathrm{~mm}$. The depth of pond is chosen as $\mathrm{H}_{\mathrm{p}}=3 \mathrm{~m}$. Therefore, the area of pond required may be interpolated as, $A_{p}=1202.436 \mathrm{~m}^{2}$.

Hence in the Contai Polytechnic College Campus, 4 ponds of area $301 \mathrm{~m}^{2}$ each are provided, depth of each pond is $3.0 \mathrm{~m}$.

\section{(d) Recharge Chamber with Recharge Well}

Adopting a total roof area in the site as $12000 \mathrm{~m}^{2}, \alpha=0.5$ and $\mathrm{R}=2259 \mathrm{~mm}$ ( maximum rainfall in last 10 years), keeping the recharge chamber dimensions as: $\mathrm{L}=2 \mathrm{~m}, \mathrm{~B}=2 \mathrm{~m}, \mathrm{H}=1.2 \mathrm{~m}$, the number of recharge chamber with recharge well has been obtained as $\mathrm{N}_{\mathrm{w}}=12$. It is also mentioned that the dimension of the recharge wells adopted here are as per the recommendation of Sarkar (2007) and are as follows:

Diameter of the well

Strainer dia in the aquifer

Length of strainer

Dia of the inlet strainer placed in the Recharge chamber

Length of $150 \mathrm{~mm}$ strainer
$100 \mathrm{~mm}$

$100 \mathrm{~mm}$

$12 \mathrm{~m}$

$150 \mathrm{~mm}$

$800 \mathrm{~mm}$

(e) As per design recommendation, the plan of the site provided with the new methodology has been given in Fig. 7. The details of the recharge well are depicted in Fig. 8.

It is hereby mentioned that the parameters for recharge, well, etc. used in the design are highly sitespecific. Successful application of the entire methodology is possible only when the design parameters are adequately chosen for a specific site.

The following significant conclusions are drawn:

\section{Conclusions}

An innovative method has been developed by the author for coastal zone groundwater management which involves withdrawal by qanat-well structures associates with equivalent artificial recharge by rainwater harvesting through percolation pond and recharge well. If adequately applied and design the proposed methodology is expected to be quite useful and convenient, for unconfined condition of the coastal aquifers.

As the suggested methodology has been applied to a selected coastal site located at Purba Midnapur district to study the various quantative aspects of the method, it was observed that depth of qanat $d$ decreases following a curvilinear pattern with the length of leg $L_{q}$. The variation is quite sharp in the range of $1 \mathrm{~m} \leq \boldsymbol{L}_{\mathscr{q}} \leq \boldsymbol{n} \boldsymbol{n}$ and assumes a linear pattern for $L_{q}>3 \mathrm{~m}$.

The factor of safety for rainwater recharge in the selected location increases linearly with increase in annual precipitation. Also, the curves relevant to those of Chaturvedi (1936) and Kumar \& Seethapathi (2002) almost coincide. Both the magnitudes and the slopes of the curves relevant to that of Wu and Zhzng (1994) are significantly high. This technique is most effective when the value of the factor of safety is slightly higher than unity. excavated.

The required area of recharge pond decreases in a hyperbolic manner with the depth of pond to be

The number of recharge chambers $N_{w}$ decreases fairly exponentially with the volume $V_{w}$ of the recharge chambers. The rate of decrease is pronounced in the range of $V_{w}<5$, beyond which a stabilizing tendency is noted.

It is hereby mentioned that the model suggested is highly site-specific. Successful application of the entire methodology is possible only when the design parameters are adequately chosen for the particular site under consideration.

\section{Appendix 1: List Notations}

$\mathrm{Q}$
$\mathrm{S}$
$\mathrm{L}$
$\mathrm{r}_{\mathrm{w}}$
$\mathrm{k}_{\mathrm{h}}$

Steady state discharge.

Drawdown above the well centre.

Length of the horizontal well.

Well radius.

Hydraulic conductivity of the aquifer along horizontal direction. 
$\mathrm{H}$

$\mathrm{k}_{\mathrm{v}}$

$\beta$

$\delta$

$\mathrm{R}$

$\mathrm{Q}_{\mathrm{q}}$

$\mathrm{L}_{\mathrm{q}}$

$\mathrm{r}_{\mathrm{q}}$

d

$\mathrm{A}_{\mathrm{t}}$

$\mathrm{A}_{\text {roof }}$

$\mathrm{A}_{\text {road }}$

$\mathrm{A}_{\text {road }}$

$\mathrm{A}_{1}$

W

P

$\mathrm{R}$

$\eta$

$\alpha$

$\mathrm{A}_{\mathrm{p}}$

$\mathrm{R}_{\mathrm{m}}$

$\eta_{1}$

$\mathrm{H}_{\mathrm{p}}$

$\mathrm{V}_{\mathrm{w}}$

$\mathrm{N}_{\mathrm{w}}$

$\mathrm{R}_{\mathrm{e}}$

$\mathrm{P}_{\mathrm{e}}$
Aquifer thickness.

Hydraulic conductivity of the aquifer along vertical direction.

$\left(\mathrm{k}_{\mathrm{h}} / \mathrm{k}_{\mathrm{v}}\right)^{0.5}$

Off-centered eccentricity of the well-centre in the vertical aquifer plane.

Radius of influence of the equivalent vertical well in the same aquifer for the same drawdown, which can be reasonably estimated using the available correlations (for example, Sichardt's formulae).

Steady state discharge from the qanat.

Length of a qanat leg

Inner radius of qanat legs

Depth of the bottom surface of the qanat legs below

the undisturbed water table.

Total area of the community

Total roof cover area for all building in the community

Total road area in the community

Total pond area of the community

Total area of vacant land in the community

Average water consumption of people in the

community in litre per capita per day (140 lit/Capita/Day)

Population of the community

Design annual rainfall in $\mathrm{mm}$

Recharge coefficient

Fraction of rainwater collected at roof which in

directed towards the recharge well.

Area of the Pond

Design monsoon rainfall in $\mathrm{mm}$.

Runoff coefficient relevant to the area

Depth of pond to be excavated

Volume of the recharge chamber in the community

Nos. of recharge chamber fitted with 100 dia.

recharge well adopted in the community

Infiltration Recharge in $\mathrm{mm}$

Effective Rainfall in mm

\section{Appendix 2: References}

1. Annual Climate Summery (2010), India Meteorological Department, Ministry of Earth Sciences, Government of India.

2. Bhattacharya A.K. (2002) "Saline water Intrusion into Coastal Aquifers of West Bengal, India", International Conference on Low Lying Coastal Areas Hydrology and Coastal Zone Management, Bremerhaven, Federal Republic of Germany, pp. 197-200.

3. Bhattacharya, A. K. and Basack, S. (2003) "Chloride and Arsenic Contamination in Groundwater in Coastal Areas of West Bengal”, Tenth West Bengal State Science and Technology Congress, $28^{\text {th }}$ February $\square 2^{\text {nd }}$ March, 2003, Midnapur , West Bengal, India.

4. Bhattacharya, A. K. and Basack, S. (2003) "Analysis and Control of Saline Water Intrusion in Coastal Aquifers with Special Emphasis on East Coast of India”, Final Technical Report, AICTE No. 8022/RID/NPROJ/RPS-82-4 dated 22/3/2004.

5. Bhattacharya, A.K., Basack, S., and Maity, P.(2010). "Groundwater Extraction in Coastal Arid Regions-A Design Methodology using Qanats", the Electronic Journal of IETECH Journal of Civil and Structures, Vol.3, No.:1, pages 017-020, [www.ietech.org].

6. Bhattacharya, A.K., Basack, S., and Maity, P. (2004) "Groundwater Extraction in the United Arab Emirates Under the Constraint of Saline Water Intrusion” the Journal of Environmental Hydrology, Vol. 12, Paper 6, No.6, April, 2004. pages 1-5.

7. Bhattacharya, A.K., Basack, S., and Maity, P.(2004)."A Feasible Method of Groundwater Extraction in the United Arab Emirates and Qatar", has been presented at, and published in the Proceedings of, the International Conference on Water Resources - Flood Control, Irrigation, Drinking Water, Waterways, Electric Power and Transmission System, 3-4 February, 2004, New Delhi. Pages 170-175.

8. Blair, D.A., Spronz, W.D. and Ryan, K.W., (1999), "Brackish Groundwater Desalination-A Community's Solution to Water Supply and Aquifer Protection”, Journal of the American Water Resources Association, Vol. 35, No. 5, pp. $1201-1212$.

9. Chaturvedi, R.S., (1973). "A Note on the Investigation of Ground Water Resources in Western Districts of Uttar Pradesh". Annual Report, U. P. Irrigation Research Institute, 1973, pp. 86-122.

10. Dagan, G. and Bear, J. (1968). "Solving the Problem of Local Interface Upconing in a Coastal Aquifer by the Method of Small Perturbations", Journal. Hydraulic Research, 6, (1), P. 15-44.

11. Drabbbe, J. and Ghyben, B. (1888) "Nota in Verband Met de Voorgenoment putboring nabji Amsterdam", Tijdschriff Van het koninklijk Institute Van Ingenieurs, The Hague, Netherlands.

12. Ghyben, W. B. (1888) "Nota in verband met de voorgenomen putboring nabij Amsterdamî", Tijdschrift Kon. Inst. Ing. pp. 8-22.

13. http://www.rainwaterharvesting.org/

14. http://www.tn.gov.in./dtp/rainwater.htm. 
15. Herzberg, B. (1901) "Wasserversorgung Einiger Nordseebader”, Journal of Gasbeleuchtung and Wasserversorgung, Vol. 44, Munich.

16. Joshi, S. D. (1986). "Augmentation of Well Productivity Using Slant and Horizontal Wells", Paper SPE 15375, presented at 61st Annual Technical Conference and Exhibition of the Society of Petroleum Engineers, New Orleans, LA.

17. Karanth, K.R (1990) "Groundwater Assessment Development and Management", Tata McGraw-Hill Publishing Co. Ltd., New Delhi.

18. Kumar, C. P. and P. V. Seethapathi (2002), "Assessment of Natural Ground Water Recharge in Upper Ganga Canal Command Area", Journal of Applied Hydrology, Association of Hydrologists of India, Vol. XV, No. 4, October 2002, pp. 13-20.

19. Lee, C.H. and Chang, T.S. (1974) "On Sea water Encroachment in Coastal Aquifers", Water Resources Research, No. 10, pp 10391043.

20. Mays, L.W. (2001) "Water Resources Engineering", John Wiley \& Sons, N.Y.

21. Patra, M. N. (2006) "Localised and Generalised Subsidence and Swelling of the ground Surface due to Change in Groundwater Piezometric Level with a Special Reference to Calcutta ", PhD thesis, Bengal Engineering and Science University, Shibpur, Howrah, India.

22. Raghu Babu M., Prasad, B. R. and Srikanth, I. (2004), "Subsurface Skimming Techniques for Coastal Sandy Soils", Bulletin No. 1/04: 18pp. A I C R P Saline Water Scheme, Bapatla.

23. Raghunath, H.M. (1987) "Ground Water", 2nd Edition, Wiley Eastern Ltd., New Delhi.

24. Sarkar, S. (2005), "A Field Study on Saline Water Intrusion into Coastal Aquifer of Purba Medinipur", M.E. thesis, Bengal Engineering and Science University, Howrah, India.

25. Sarkar, A. (2007), "Design of Rainwater Harvesting Scheme for Water Conservation for Fire Fighting \& others and Artificial Recharge to Groundwater at TCS main building campus, Salt Lake, Kolkata", A Scheme design report as a consultancy submitted to Tata Consultancy Services limited, Dec. 2007.

26. State Forest Report (2008-09), Office of the Principal Chief Conservator of Forests, Kolkata, Directorate of Forests, Government of West Bengal, India.

27. United Nations Development Programme Report (2006), "Human Development Report 2006 Beyond Scarcity: Power, Poverty and Global Water Crisis", ISBN 0-230-50058-7.

28. United Nations Environment Programme Report (2009), "Rainwater Harvesting: A Lifeline for Human Well-Being", A report prepared for UNEP by Stockholm Environment Institute, ISBN: 978 - 92 - 807 - 3019 - 7, Job No. DEP/1162/NA.

29. Wood, E. F., Sivapalan, M. and Beven, K. (1986), "Scale Effects in Infiltration and Runoff Production", Proceedings of the Budapest Symposium, IAHS, No. 156, pp. 375-387.

30. World Health Organization Report (2010), "Progress on Sanitation and Drinking Water - 2010 Update", WHO/UNICEF Joint Monitoring Programme for Water Supply and Sanitation, ISBN 978924156395 6, NLM classification: WA 670.

31. Wu, J. and Zhang, R. (1994), “Analysis of Rainfall Infiltration Recharge to Groundwater", Proceedings of Fourteenth Annual American Geophysical Union: Hydrology Days, Colorado, USA, pp. 420-430.

\section{Drawdown curve \\ Vertical riser \\ 4-legged ganat}

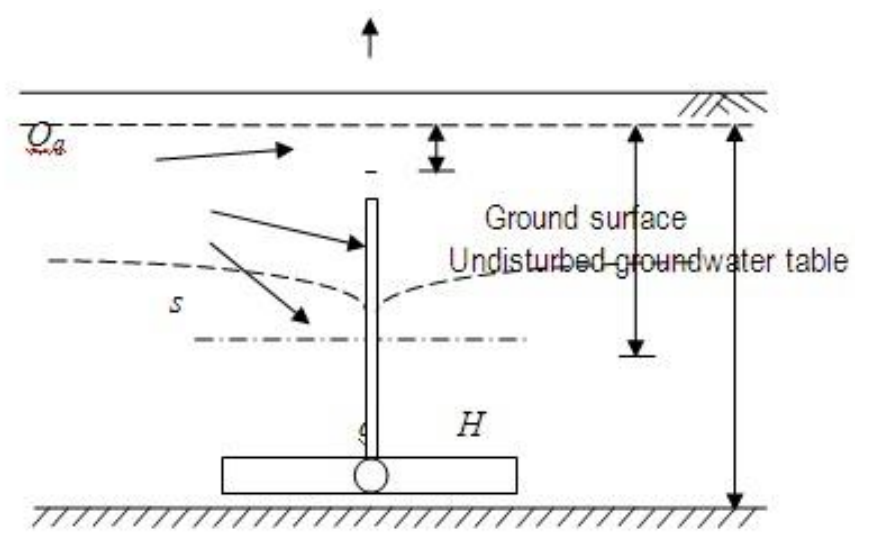

Impervious boundary

\section{SECTIONAL ELEVATION}

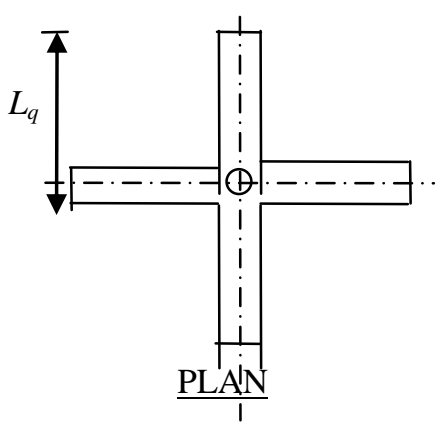


Fig. 1 : A typical 4-legged qanat.

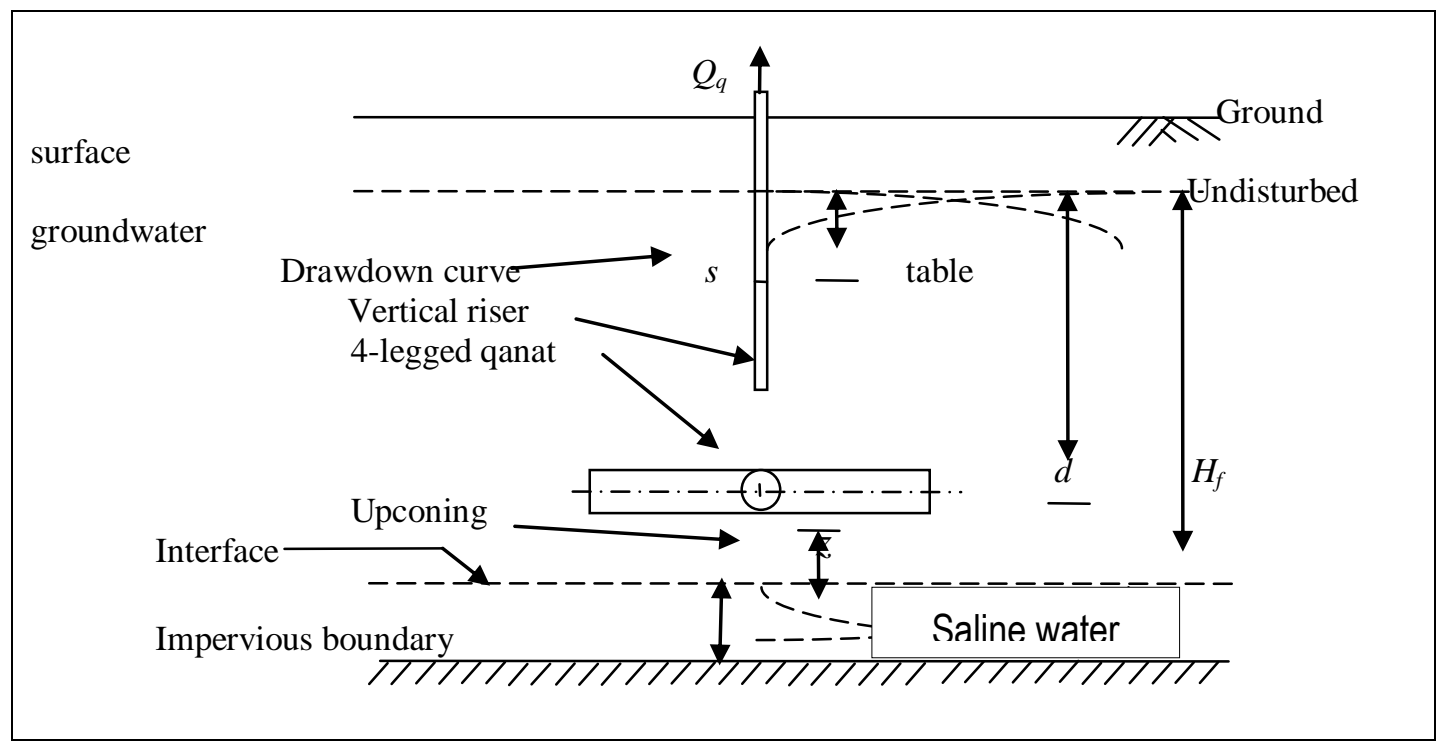

Fig. 2: Withdrawal of groundwater by qanat in salinity affected aquifer.
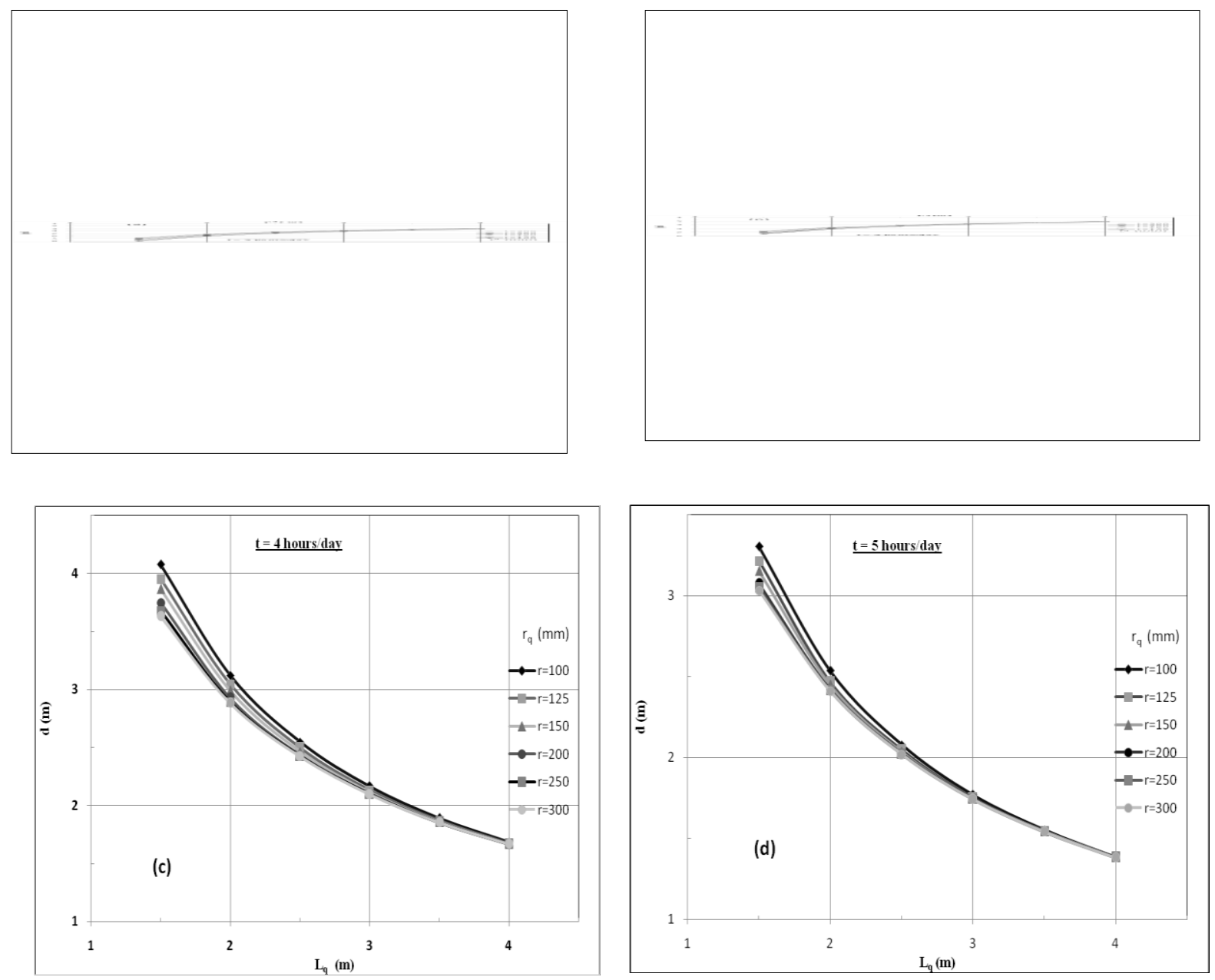

Fig. 3: Variation of depth of qanat at base versus length of qanat leg for pumping duration (in hours per day), $t$ : (a) 2. (b) 3. (c) 4. (d) 5 . 


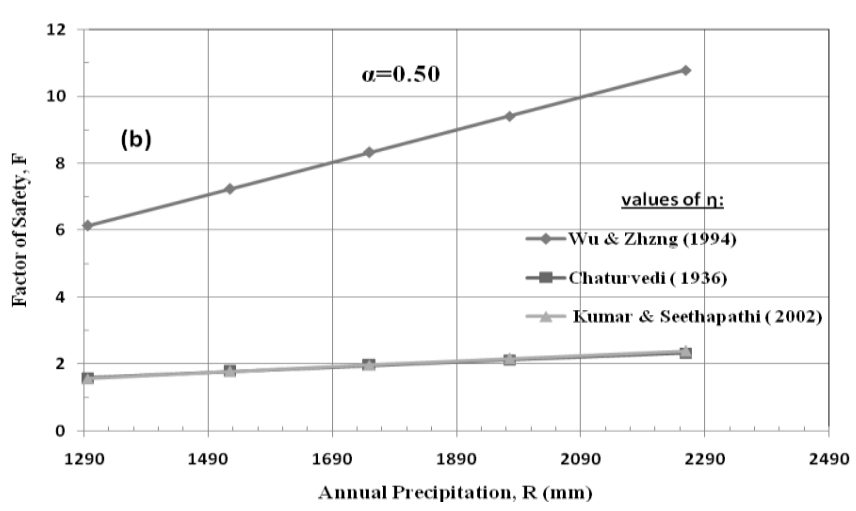

( c)

Fig. 4: Variation of the factor of safety $F$ with annual precipitation $R$ for:

(a) $\alpha=0.25$. (b) $\alpha=0.50$, and (c) $\alpha=0.75$.

(a)

(b)

(c)

(d)

Fig. 5: Plots of area of recharge pond versus depth of pond for monsoon precipitation:

(a) $200 \mathrm{~mm}$. (b) $350 \mathrm{~mm}$. (c) $500 \mathrm{~mm}$, and (d) $750 \mathrm{~mm}$. 
$\mathrm{mm}$, and (d) $750 \mathrm{~mm}$.

(a) $200 \mathrm{~mm}$. (b) $350 \mathrm{~mm}$. (c) 500

(c)

Fig. 6: Variation of recharge chamber volume with number with annual precipitation $\mathbf{R}$ for: (a) $1296 \mathrm{~mm}$, (b) $1525 \mathrm{~mm}$, (c) $1750 \mathrm{~mm}$, (d) $1975 \mathrm{~mm}$, and (e) $2259 \mathrm{~mm}$. 
Fig. 7 : Contai Polytechnic College Campus area showing location of qanat-well structures, percolation ponds and recharge chambers with recharge wells.
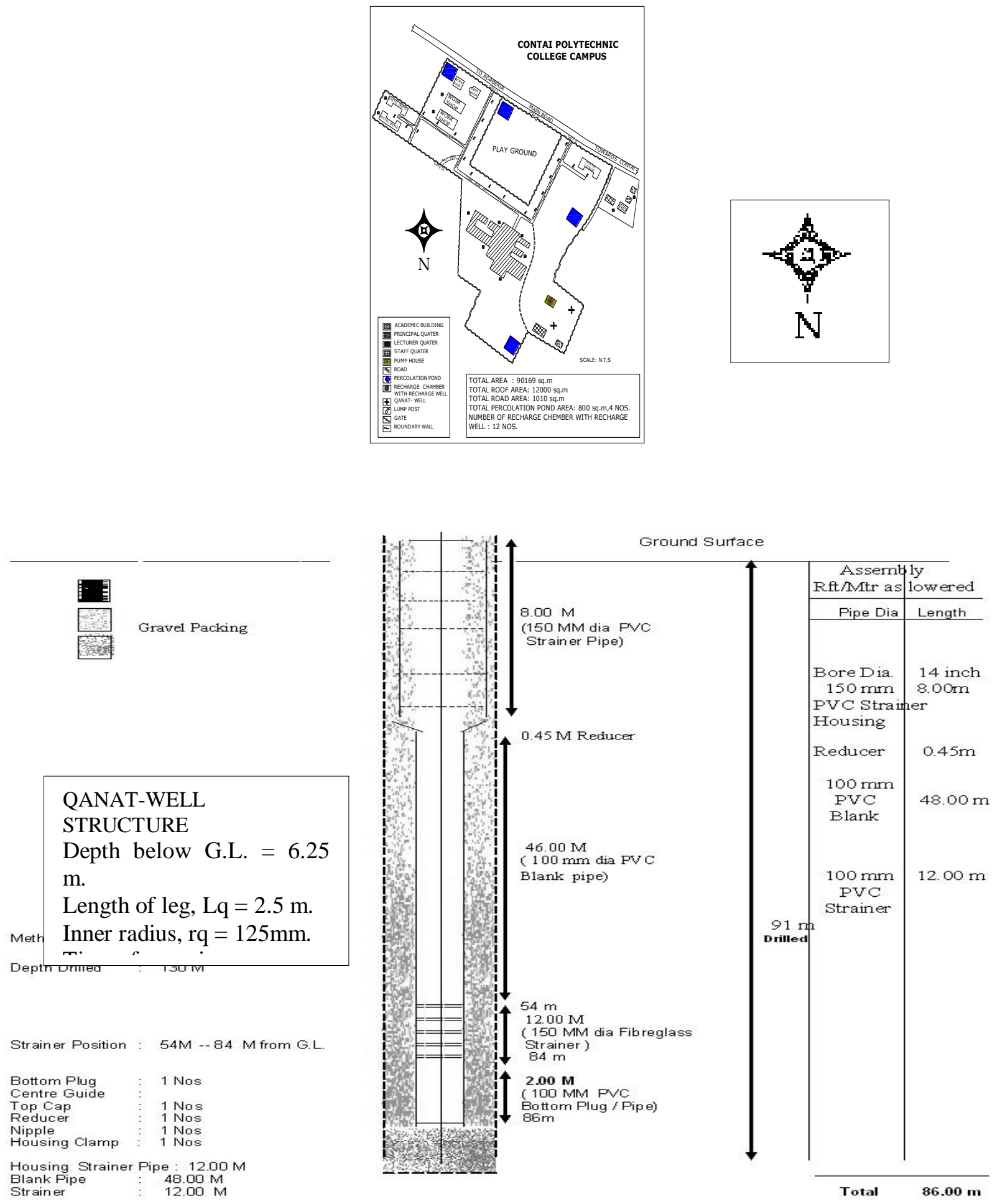

Fig. 8: Cross section of recharge well adopted. 